ISSN: $1858-4837$

E-ISSN: 2598-019X

Volume 14, Nomor 2 (2019),

https://jurnal.uns.ac.id/region

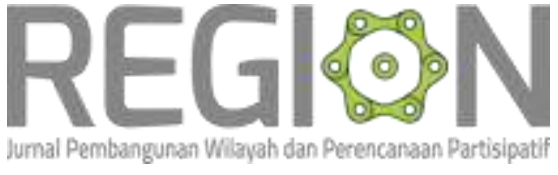

\title{
Pengaruh Karakter Spasial Pola Hulu Hilir Pertanian Padi Organik Terhadap Peningkatan Ekonomi Pedesaan, Gempol, Klaten
}

\author{
The Influence Of Spatial Characteristic Upstream Downstream Pattern \\ of Organic Rice Agriculture on Rural Economy Improvement, Gempol, \\ Klaten
}

\author{
Martha Dwi Nugrahaeni ${ }^{a}$, Aliyah ${ }^{b}$, Yudana $^{c}$ \\ aProgram Studi Perencanaan Wilayah dan Kota, Fakultas Teknik, Universitas Sebelas Maret \\ ${ }^{b}$ Program Studi Perencanaan Wilayah dan Kota, Fakultas Teknik, Universitas Sebelas Maret \\ cProgram Studi Perencanaan Wilayah dan Kota, Fakultas Teknik, Universitas Sebelas Maret \\ *Corresponding author's email: martha.nugrahaeni@gmail.com
}

\begin{abstract}
Abstrak
Analisis spasial terfokus pada identifikasi karakter spasial dan pola spasial. Teori Von Thunen mencoba menjelaskan hubungan antara karakter spasial yang terbentuk dalam kegiatan ekonomi pertanian (Rustiadi, et.al, 2011). Hulu hilir pertanian padi organik meliputi karakter spasial pola pengadaan bahan baku, budidaya, dan pasar. Pertanian organik memberikan dampak positif terhadap perkembangan ekonomi pedesaan. Perkembangan pertanian organik di Desa Gempol dari tahun 2016 sampai dengan 2018 telah mengalami peningkatan yang cukup signifikan yang memberikan pengaruh terhadap pertumbuhan ekonomi di Desa Gempol. Karakter spasial pola hulu hilir pertanian padi organik memiliki pengaruh terhadap peningkatan ekonomi pedesaan. Berdasarkan analisis spasial diketahui bahwa pola pengadaan bahan baku dilakukan secara terpusat dengan proses pendistribusian melalui Karang Taruna dan Wanita Tani; pola lokasi budidaya adalah pola menggerombol, dan pola pasar yang terbentuk adalah menyebar. Berdasarkan analisis skoring diketahui bahwa karakter spasial pola hulu hilir pertanian padi organik memiliki pengaruh yang kuat. Analisis peningkatan ekonomi pedesaan dilakukan dengan teknik skoring. Peningkatan ekonomi yang terjadi di Desa Gempol dari Tahun 2016-2018 adalah peningkatan tinggi. Analisis dengan software SPSS digunakan untuk mengetahui pengaruh karakter spasial pola hulu hilir pertanian padi organik terhadap peningkatan ekonomi pedesaan. Berdasarkan analisis regresi linear berganda diketahui bahwa tingkat pengaruh karakter spasial pola hulu hilir pertanian padi organik terhadap jejaring ekonomi pertanian, jumlah tenaga kerja, upah tenaga kerja, serta biaya adalah pengaruh kuat.
\end{abstract}

Kata Kunci: Ekonomi Pedesaan, Hulu Hilir Pertanian Padi Organik, Karakter Spasial, Pengaruh, Pola Spasial

\begin{abstract}
Spatial analysis focuses on the identification of spatial characters and spatial patterns. Von Thunen's theory attempts to explain the relationship between the spatial character formed in agricultural economic activity (Rustiadi et al., 2011). Upstream downstream organic rice farming includes the spatial character of the procurement patterns of raw materials, cultivation, and markets. Organic farming has a positive impact on the development of rural economy. The development of organic farming in Gempol Village from 2016 to 2018 has experienced a significant increase that gives effect to economic growth in Gempol Village. The spatial character of the upstream rice farming organic rice pattern has an influence on improving the rural economy. Based on spatial analysis, it is known that the pattern of raw material procurement is done centrally by distribution process through Karang Taruna and Wanita Tani; the pattern of the location of the
\end{abstract}


Martha Dwi Nugrahaeni, dkk, Pengaruh Karakter...

cultivation is the pattern of bunching, and the market pattern that is formed is spread. Based on scoring analysis it is known that the spatial character of the upstream rice organic rice has a strong influence. Analysis of rural economy improvement is done by scoring technique. The economic improvement that occurred in Gempol Village from the Year 2016-2018 is a high increase. Analysis with SPSS software is used to determine the effect of spatial characteristic of upstream rice pattern of organic rice farming to rural economy improvement. Based on multiple linear regression analysis, it is known that the level of influence of spatial character of upstream organic rice farming pattern toward agricultural economic network, number of labor, labor wage, and cost is strong influence.

Keywords: Influence, spatial character, spatial pattern, upstream downstream organic rice farm, rural economy

\section{PENDAHULUAN}

Kabupaten Klaten merupakan lumbung padi nasional semenjak tahun 2009. Pengembangan pertanian berkelanjutan diharapkan mampu menjadi pendorong bagi sektor ekonomi. Desa Gempol merupakan desa di Kabupaten Klaten yang sudah memperoleh sertifikat dari Kementrian Pertanian dan LeSOS (Lembaga Sertifikasi Organik Seloliman) Nomor 144-LSPO-005-IDN-07-16 untuk Ruang Lingkup Padi Organik semenjak 16 Juli 2016. Untuk dapat memperoleh sertifikat tersebut maka petani dan aparat pemerintah Desa Gempol melakukan uji coba sesuai dengan SOP yang telah ditentukan, mulai dari proses pemilihan lokasi hingga proses pemasaran. Proses tersebut tidak didapatkan secara instan, pada tahun 2008 para petani mulai mencoba mengubah pola pikir untuk memperbaiki kondisi fisik, sosial, dan ekonomi.

Dampak yang dirasakan setelah memperoleh sertifikat tersebut bukan hanya untuk kesehatan dan kualitas lingkungan, tetapi juga peningkatan ekonomi pedesaan Desa Gempol. Ekonomi pedesaan erat kaitannya dengan bidang pertanian. Ekonomi pedesaan lebih terkonsentrasi dengan pendekatan yang sesuai dengan sifat dan ciri khasnya (Syahza, 2013). Pelaksanaan hulu hilir yang ada akan membentuk sebuah karakter spasaial berupa pola yang didukung dengan jaringan transportasi yang ada, dapat menjadikan sebagai potensi untuk upaya peningkatan perekonomian masyarakat. Dari kegiatan-kegiatan tersebut maka dapat membentuk sebuah pola secara spasial. Mulai dari proses pengadaan bahan baku, proses budidaya, sampai dengan proses pemasaran yang memberikan efek positif terhadap peningkatan ekonomi Desa Gemopol.

Berdasarkan hal tersebut maka timbul rumusan masalah bagaimana pengaruh karakter spasial pola hulu hilir pertanian padi organik terhadap peningkatan ekonomi pedesaan. Sehingga tujuan dari penelitian ini adalah menganalisis pengaruh karakter spasial pola hulu hilir pertanian padi organik terhadap 
Region, Vol. 14, No.2, Januari 2019: 244-266

peningkatan ekonomi pedesaan. Untuk mencapai tersebut digunakan teknik analisis spasial untuk mengetahui bagaimana pola hulu hilir pertanian padi organik yang terbentuk, teknik skoring untuk mengetahui bagaimana pengaruh karakter spasial yang ada serta seberapa besar peningkatan ekonomi yang terjadi. Selanjutnya untuk mengetahui pengaruh keduanya maka menggunakan teknik analisis regresi linear berganda dengan menggunakan software SPSS. Berdasarkan analisis tersebut diketahui bahwa karakter spasial pola hulu hulir pertanian padi organik memberikan pengaruh yang kuat terhadap masing-masing komponen peningkatan ekonomi pedesaan.

\section{KAJIAN TEORI}

\subsection{Pertanian Padi Organik}

Pertanian organik merupakan pertanian ramah lingkungan tanpa menggunakan input bahan kimia yang merusak keseimbangan lingkungan serta memanfaatkan sumberdaya lokal (SNI 01-6729-2002; Saragih, 2010; Sriyanto, 2010; Mayrowani, 2012; Tuoministo et.al., 2012). Pertanian organik bertujuan untuk meningkatkan kesehatan dan keanekaragaman agroekosistem alami (SNI 01-6729-2002; Mayrowarni, 2012; Bengtsson, 2015) selain itu pertanian organik memberikan keuntungan yang lebih besar di bidang ekonomi karena harga jual produk organik lebih tinggi (Mayrowani, 2012).

\subsection{Hulu Hilir Pertanian Padi Organilk}

Hulu hilir pertanian padi organik mengadopsi dari teori agribisnis, karena sudah merepresentasikan proses hulu (pengadaan bahan baku) sampai ke hilir (proses pendistribusian produk) pertanian. Sistem hulu merupakan sistem pra panen yang meliputi pembenihan, pembuatan pupuk atau proses pengadaan bahan baku (Saragih, 1899; SOP Kel. Tani Dewi Ratih II, 2016). Subsistem budidaya merupakan teknik budidaya padi organik (Madi et.al., 2003). Sedangkan subsistem hilir adalah kegiatan pascapanen yaitu proses pengolahan dan proses pemasaran (Said \& A.H., 2001).

\subsection{Karakter dan Pola Spasial}

Spasial adalah segala sesuatu hal yang menyangkut lokasi dan tempat. Ilustrasi spasial bertujuan menjelaskan karakter spasial. Analisis spasial berfokus pada identifikasi pola serta pemodelan spasial agar mudah dimengerti. Analisi pola meliputi pemusatan, penyebaran, kompleksitas spasial, interaksi spasial yang dirumuskan secara deskriptif (Rustiadi, et.al., 2011). 
Martha Dwi Nugrahaeni, dkk, Pengaruh Karakter..

Pola memusat merupakan pola yang dikemukakan oleh Burgess, terdapat satu pusat yang kemudian dari pusat tersebut terjadi perluasan ke zona-zona sekitarnya sehingga membuat zona konsentris. Pola pasar yang terbentuk sesuai dengan teori August Losch dalam (Budiharsono, 2001) tentang teori market area. Apabila luas pasar yang dikuasai semakin besar maka keuntungan yang didapatkan akan semakin besar. Menurut (Bertrand, 1978) pola pasar yang tersebar yang dimungkinkan karena perbedaan produksi dan permintaan sehingga dapat disebut juga trade center community.

\subsubsection{Teori Lokasi}

Pola pengadaan lahan pertanian disebut locational rent. Teori lokasi Von Thunen mempertimbangkan efisiensi tenaga kerja dan aspek ekonomi. Penentuan lokasi dapat dikaitkan dengan kemudahan akses, jarak tempuh, biaya transportasi, dan moda transportasi. Selain itu lokasi yang optimum adalah lokasi yang mendekati bahan baku ataupun yang mendekati pasar (Von Thunen, 1824; Weber, 1909; Losch, 1943; Isard, 1956; Smith, 1987).

\subsubsection{Jaringan jalan}

Hierarki jalan menurut SNI Menurut SNI Nomor 03-6967-2003, jalur selebar $\pm 4 \mathrm{~m}$ yang ada dalam satuan permukiman atau lingkungan perumahan. Lebar jalan arteri adalah >8m sedangkan jalan kolektor dengan lebar >7m (Mirsa, 2012). 


\subsection{Hubungan Hulu Hilir Pertanian Padi Organik dengan Karakter Spasial}

Tabel 1. Hubungan Hulu Hilir Pertanian Padi Organik dengan Karakter dan Pola Spasial

\begin{tabular}{|c|c|c|c|c|c|c|}
\hline $\begin{array}{l}\text { Karakter dan } \\
\text { pola spasial } \\
\text { Hulu hilir } \\
\text { pertanian } \\
\text { padi organilk }\end{array}$ & $\begin{array}{l}\text { Karakter } \\
\text { spasial sebuah } \\
\text { wilayah } \\
\text { terbentuk dari } \\
\text { titik, garis, } \\
\text { serta area } \\
\text { yang } \\
\text { membentuk } \\
\text { pola spasial }\end{array}$ & $\begin{array}{l}\text { Pola } \\
\text { guna } \\
\text { lahan } \\
\text { pertanian } \\
\text { dengan } \\
\text { locational } \\
\text { rent }\end{array}$ & $\begin{array}{l}\text { Pola } \\
\text { lokasi } \\
\text { pasar } \\
\text { dengan } \\
\text { market } \\
\text { area } \\
\text { theories }\end{array}$ & $\begin{array}{l}\text { Penentuan lokasi } \\
\text { dikaitkan dengan: } \\
\text {-kemudahan alkses; } \\
\text { - jarak; } \\
\text { - biaya transportasi; } \\
\text { - moda transportasi; }\end{array}$ & $\begin{array}{lr}\text { Lolkasi } & \text { optimum } \\
\text { merupakan lokasi } \\
\text { yang } \text { mendekati } \\
\text { bahan } & \text { baku } \\
\text { maupun } & \text { lokasi } \\
\text { pasar } & \end{array}$ & $\begin{array}{l}\text { Jalan } \\
\text { sesuai } \\
\text { standar } \\
\text { telknis }\end{array}$ \\
\hline \multicolumn{7}{|l|}{$\begin{array}{l}\text { Sistem terpadu } \\
\text { untuk } \\
\text { pertumbuhan } \\
\text { elkonomi }\end{array}$} \\
\hline $\begin{array}{l}\text { Pengadaan } \\
\text { baham baku }\end{array}$ & $\begin{array}{l}\text { Karakter spasial } \\
\text { proses } \\
\text { pengadaan } \\
\text { bahan baku }\end{array}$ & & & $\begin{array}{l}\text { - lokasi bahan baku } \\
\text { mudah diakses } \\
\text { - biaya transportasi } \\
\text { pengadaan bahan baku }\end{array}$ & $\begin{array}{lr}\text { Lokasi } & \text { yang } \\
\text { mendekati } & \text { lokasi } \\
\text { bahan } & \text { baku } \\
\text { merupakan } & \text { lokasi } \\
\text { optimum } & \\
\end{array}$ & $\begin{array}{l}\text { Jalan } \\
\text { sesuai } \\
\text { standar } \\
\text { teknis }\end{array}$ \\
\hline $\begin{array}{l}\text { Proses } \\
\text { budidaya }\end{array}$ & $\begin{array}{l}\text { Karakter spasial } \\
\text { proses } \\
\text { budidaya }\end{array}$ & & & $\begin{array}{l}\text { - lokasi budidaya } \\
\text { mudah diakses } \\
\text { - jarak menuju lokasi } \\
\text { budidaya dari lokasi } \\
\text { bahan baku dan lokasi } \\
\text { pasar }\end{array}$ & $\begin{array}{l}\text { Lokasi optimum } \\
\text { merupakan lokasi } \\
\text { yang mendekati } \\
\text { lokasi bahan baku } \\
\text { dan pasar }\end{array}$ & $\begin{array}{l}\text { Jalan } \\
\text { sesuai } \\
\text { standar } \\
\text { teknis }\end{array}$ \\
\hline Pasar & $\begin{array}{l}\text { Karakter spasial } \\
\text { pasar }\end{array}$ & & & $\begin{array}{l}\text { - lokasi pasar mudah } \\
\text { diakses } \\
\text { - jarak menuju pasar } \\
\text { - biaya transportasi } \\
\text { menuju pasar } \\
\text { - moda transportasi } \\
\text { menuju pasar }\end{array}$ & $\begin{array}{lr}\text { Lokasi } & \text { optimum } \\
\text { merupakan lokasi } \\
\text { yang mendekati } \\
\text { pasar }\end{array}$ & $\begin{array}{l}\text { Jalan } \\
\text { sesuai } \\
\text { standar } \\
\text { teknis }\end{array}$ \\
\hline
\end{tabular}

Sumber: Nugrahaeni, 2018

\subsection{Peningkatan Ekonomi Pedesaan}

Pedesaan merupakan kawasan dengan kegiatan ekonomi utama pertanian (UU No. 26/2007). Pembangunan pedesaan dapat dilakukan sesuai dengan ciri khasnya yaitu pemberdayaan ekonomi masyarakat desa, peningkatan kualitas SDM, pembangunan sarana prasana, membangun kelembagaan yang baik (Syahza, 2013).

\subsubsection{Jejaring Elkonomi Pertanian}

Pengelolaan rantai pasok adalah salah satu alat, metode dan pendekatan untuk mengelola pola jaringan ekonomi (Pujawan, 2005). Rantai pasok terdapat tiga tahapan dalam aliran material. Bahan mentah didistribusikan ke manufaktur membentuk sebuah sistem kemudian diolah dan didistribusikan pada konsumen akhir sehingga membentuk sistem distribusi (Maghfiroh, 2010). 
Martha Dwi Nugrahaeni, dkk, Pengaruh Karakter...

\subsubsection{Ketenagakerjaan}

Menurut Hermanto, 1989 tenaga kerja merupakan salah satu faktor produksi. Tenaga kerja dapat berasal dari keluarga petani maupun keluarga non petani. Biaya yang dikeluarkan untuk sistem upah tenaga kerja petani terdiri dari upah borongan, upah waktu, dan upah premi. Masing-masing sistem tersebut akan mempengaruhi kinerja dari petani tersebut (Tohir, 1983).

\subsubsection{Pembiayaan Usaha Tani}

Analisis ushatani perlu diketahui komponen penerimaan, biaya, dan pendapatan. Menurut Soekartawi dalam (Supartama, et al., Juni, 2013) analisis terhadap tiga variabel tersebut sering disebut dengan analisis anggaran arus uang tunai (cashflow analysis), berikut rumus umum cahsflow analysis:

\section{Pendapatan $=$ Penerimaan - Biaya}

Ada empat unsur pokok dalam usahatani yang sering disebut sebagai faktor-faktor produksi (Hermanto, 1989) yaitu tanah, tenaga kerja, modal dan pengelolaan atau manajemen.

\subsection{Hubungan Karakter Spasial Pola Hulu Hilir Pertanian Padi Organik dengan Peningkatan Ekonomi Pedesaan}

Terdapat hubungan antara kegiatan yang membentuk pola hulu hilir pertanian padi organik dengan peningkatan ekonomi pedesaan. Pola hulu hilir pertanian padi organik terbentuk melalui teori hulu hilir padi organik dan teori lokasi sehingga membentuk sebuah pola spasial. Pola kegiatan spasial meliputi arus modal, arus tenaga kerja, arus komoditas, dan komunikasi dalam tata ruang. Pola spasial terbentuk dari pola kegiatan serta pola fisik (Adisasmita, 2010).

Pola arus faktor produksi dan komoditas antar tata ruang wilayah yang optimal dapat terbentuk dari keseimbangan antara pemusatan atau penyebaran yang menentukan struktur lokasional ekonomi, dapat berupa pusat-pusat kegiatan, sehingga struktur tersebut dapat menjelaskan hubungannya dengan pola tersebut (Adisasmita, 2008).

Konsep tata ruang ekonomi dapat dikaitkan dengan modal, jaringan transportasi, industri, teknologi pertanian yang menciptakan perkembangan baru (Adisasmita, 2010). Dalam menganalisis tata ruang yang berimplikasi pada ekonomi maka yang sangat menjadi point adalah mata rantai transportasi atau jalan yang menimbulkan suatu arus komoditas tertentu. Organisasi spasial sistem produksi dipengaruhi oleh produk spesifik yang diminta oleh pasar serta jarak lokasi produksi dengan lokasi 
Region, Vol. 14, No.2, Januari 2019: 244-266

pasar yang menimbulkan biaya. Model spasial dari sistem produksi dapat mempengaruhi besar kecilnya biaya yang dikeluarkan dalam proses produksi (Rustiadi, et al., 2011). Kesejahteraan masyarakat di desa juga akan tercipta, sebab masyarakat desa merasakan keuntungan yang lebih dari pertanian organik (Sriyanto, 2010).

\subsection{Sintesa Variabel}

Sintesa variabel karakter spasial pola hulu hilir pertanian padi organik diperoleh dari hubungan hulu hilir pertanian padi organik dengan karakter dan pola spasial.

Tabel 2. Sintesa Variabel Karakter Spasial Pola Hulu Hilir Pertanian Padi Organik

\begin{tabular}{|c|c|c|c|}
\hline Variabel & Sub Variabel & Definisi Operasional & Sumber Teori \\
\hline \multirow{4}{*}{$\begin{array}{l}\text { Bahan } \\
\text { Baku }\end{array}$} & Asal bahan baku & $\begin{array}{l}\text { Bahan baku terletak tidak jauh dari lokasi } \\
\text { budidaya }\end{array}$ & $\begin{array}{l}\text { - Weber } 1909 \\
\text { - Baroto } 2002 \\
\text { - Ahrayi } 2003 \\
\end{array}$ \\
\hline & $\begin{array}{l}\text { Prasarana jalan } \\
\text { lokasi bahan baku }\end{array}$ & $\begin{array}{l}\text { Prasarana jalan merupakan kondisi jalan yang ada } \\
\text { di lokasi pengadaan bahan baku }\end{array}$ & $\begin{array}{l}\text { - SNI 03-6967- } \\
2003 \\
\text { - Mirsa } 2012 \\
\end{array}$ \\
\hline & $\begin{array}{l}\text { Cara menghimpun } \\
\text { bahan baku }\end{array}$ & $\begin{array}{l}\text { Cara untuk mendapatkan bahan baku baik } \\
\text { diperoleh secara langsung dari produsen, melalui } \\
\text { perantara ataupun diproduksi sendiri. }\end{array}$ & $\begin{array}{l}\text { - Baroto } 2002 \\
\text { - Ahrayi } 2003\end{array}$ \\
\hline & $\begin{array}{l}\text { Moda transportasi } \\
\text { menuju lokasi } \\
\text { bahan baku }\end{array}$ & $\begin{array}{l}\text { Moda yang digunakan untuk proses distribusi } \\
\text { bahan baku }\end{array}$ & - Losch 1954 \\
\hline \multirow{3}{*}{ Budidaya } & Lokasi budidaya & $\begin{array}{l}\text { Lokasi budidaya yang optimal merupakan lokasi } \\
\text { yang mudah dijangkau }\end{array}$ & $\begin{array}{l}\text { - Von Thunen } \\
1842 \\
\text { - Weber } 1909\end{array}$ \\
\hline & $\begin{array}{l}\text { Jarak lokasi bahan } \\
\text { baku dengan } \\
\text { budidaya }\end{array}$ & $\begin{array}{l}\text { Untuk mempertimbangkan peningkatan } \\
\text { pendapatan maka perlu memperhatikan faktor } \\
\text { jarak. Jarak budidaya merupakan jarak dari lokasi } \\
\text { pengadaan bahan baku optimal adalah jarak rata- } \\
\text { rata menuju kecamatan dan kabupaten }\end{array}$ & $\begin{array}{l}\text { - Soehardi } 1992 \\
\text { - Zulkarnaen dan } \\
\text { Setiawan } 2013\end{array}$ \\
\hline & $\begin{array}{l}\text { Prasarana jalan } \\
\text { lokasi budidaya }\end{array}$ & $\begin{array}{l}\text { Prasarana jalan merupakan kondisi jalan yang ada } \\
\text { di lokasi pengadaan bahan baku }\end{array}$ & $\begin{array}{l}\text { SNI 03-6967- } \\
2003 \\
\text { - Mirsa } 2012 \\
\end{array}$ \\
\hline \multirow{3}{*}{ Pasar } & Lokasi pasar & $\begin{array}{l}\text { Lokasi pasar yang optimal adalah pasar yang } \\
\text { memliki jangkauan yang luas }\end{array}$ & $\begin{array}{l}\text { - Von Thunen } \\
1826 \\
\text { - Losch } 1954 \\
\text { - Isard } 1959 \\
\text { - Smith } 1987 \\
\end{array}$ \\
\hline & $\begin{array}{l}\text { Jarak lokasi } \\
\text { budidaya dengan } \\
\text { lokasi pasar }\end{array}$ & $\begin{array}{l}\text { Jarak optimal adalah rata-rata jarak lokasi } \\
\text { budidaya ke lokasi pasar adalah rata-rata jarak } \\
\text { lokasi budidaya menuju kecamatan dan kabupaten }\end{array}$ & $\begin{array}{l}\text { - Soehardi } 1992 \\
\text { - Zulkarnaen dan } \\
\text { Setiawan } 2013 \\
\end{array}$ \\
\hline & $\begin{array}{l}\text { Moda transportasi } \\
\text { menuju lokasi } \\
\text { pasar }\end{array}$ & $\begin{array}{l}\text { Moda transportasi untuk mengangkut hasil } \\
\text { budidaya untuk menuju ke lokasi pasar }\end{array}$ & $\begin{array}{l}\text { - Von Thunen } \\
1842 \\
\text { - Losch } 1954\end{array}$ \\
\hline
\end{tabular}

Sumber: Nugrahaeni, 2018

Sintesa variabel peningkatan ekonomi diperoleh dari hasil sintesa teori peningkatan pedesaan. Berikut merupakan penjelasan variabel peningkatan ekonomi pedesaan: 
Martha Dwi Nugrahaeni, dkk, Pengaruh Karakter...

Tabel 3. Sintesa Variabel Peningkatan Ekonomi Pedesaan

\begin{tabular}{|c|c|c|c|}
\hline Variabel & Sub Variabel & Definisi Operasional & Sumber Teori \\
\hline $\begin{array}{l}\text { Jaringan } \\
\text { ekonomi } \\
\text { pertanian }\end{array}$ & Rantai pasok & $\begin{array}{l}\text { Jaringan yang menghubungkan antara } \\
\text { produsen dan konsumen, serta pola pemasaran }\end{array}$ & •Punjawa, 2005 \\
\hline \multirow{2}{*}{ Tenaga Kerja } & $\begin{array}{l}\text { Jumlah tenaga } \\
\text { kerja }\end{array}$ & Jumlah tenaga kerja mengalami peningkatan & $\begin{array}{l}\text { - Hermanto, } 1989 \\
\text {-Syahza, } 2007\end{array}$ \\
\hline & tenaga & $\begin{array}{l}\text { Upah yang dibayarkan kepada pekerja atas } \\
\text { hasil pekerjaan yang dilakukan }\end{array}$ & $\begin{array}{l}\text { - Tohir, } 1983 \\
\text { - Daniel. } 2012\end{array}$ \\
\hline Biaya & - & $\begin{array}{l}\text { Biaya yang dikeluarkan selama proses } \\
\text { produksi dan pengolahan }\end{array}$ & - Hermanto, 1989 \\
\hline Pendapatan & - & $\begin{array}{l}\text { Penerimaan yang diterima setelah dikurangi } \\
\text { dengan biaya total }\end{array}$ & - Hermanto, 1989 \\
\hline
\end{tabular}

Sumber: Nugrahaeni, 2018

\section{METODE}

Pendekatan pada penelitian ini adalah pendekatan deduktif dengan jenis penelitian kuantatif. Proses pengumpulan data dilakukan dengan melakukan survei primer berupa penyebaran kuesioner pada petani di Desa Gempol untuk mengetahui pengaruh karakteristik spasial pola hulu hilir pertanian padi organik terhadap peningkatan ekonomi pedesaan, observasi lapangan, dan melakukan survei data sekunder. Sampel penelitian ini adalah seluruh populasi yaitu 51 petani. Data tersebut kemudian dianalisis dengan menggunakan analisis spasial, analisis skoring, serta analisis regresi berganda dengan software SPSS. Berikut merupakan kerangka analisis pada penelitian ini:

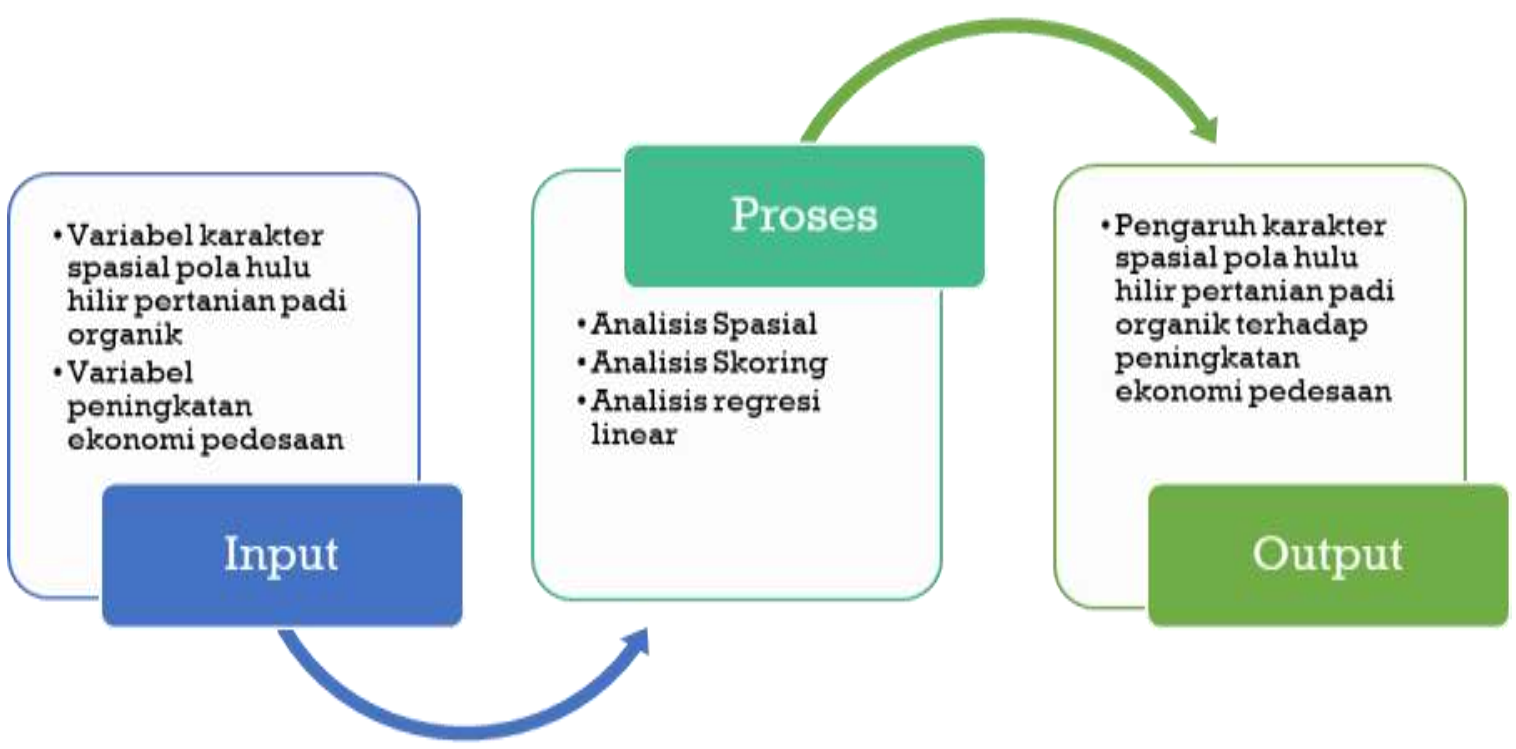

Gambar 1. Kerangka Analisis Penelitian

(Nugrahaeni, 2018) 


\section{HASIL DAN PEIMBAHASAN}

4.1 Gambaran Umum

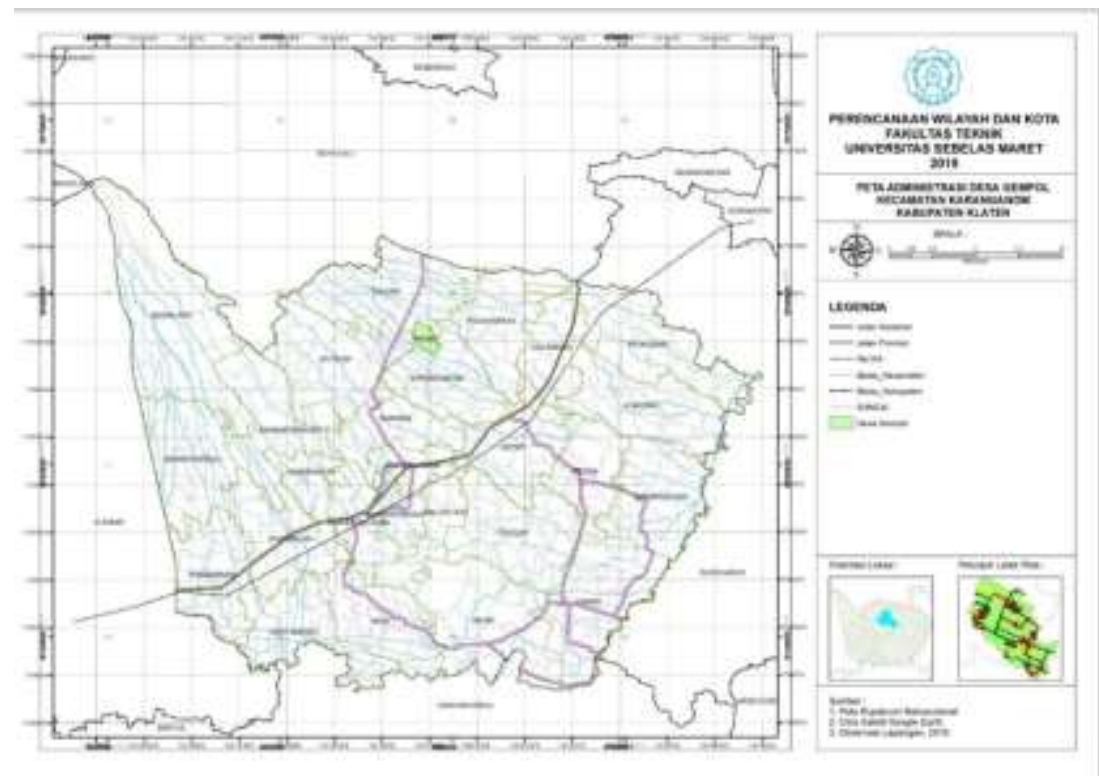

Gambar 2. Kawasan Penelitian Desa Gempol dalam Kabupaten Klaten

Desa Gempol merupakan desa yang terletak di Kecamatan Karanganom, Kabupaten Klaten. Luas Desa Gempol adalah 154,622 Ha, yang berbatasan langsung dengan sebelah utara: Desa Dalangan, sebelah Selatan: Desa Soropaten, sebelah Barat: Desa Majegan, dan sebelah Timur: Desa Pondok

Jumlah penduduk menurut jenis kelamin yaitu laki-laki 1180 orang sedangkan perempuan 1220 orang. Mayoritas mata pencaharian penduduk Desa Gempol adalah petani. Petanian merupakan sektor unggulan di Desa Gempol karena mayoritas pekerjaan penduduk di Desa Gempol adalah sebagai Petani.

Penggunaan lahan di Desa Gempol di dominasi oleh lahan pertanian, yaitu lahan pertanian seluas $110 \mathrm{Ha}$, sedangkan sisanya $44 \mathrm{Ha}$ digunakan untuk permukiman, sarana perkantoran, dan fasilitas umum lainnya. Desa Gempol merupakan satu-satunya desa dengan pertanian organik yang sudah memeliki sertifikat dari LeSOS Nomor 144-LSPO-005-IDN-07-16 untuk Ruang Linkup Padi Organik. Pertanian padi organik di Desa Gempol tersebar di beberapa dusun. yaitu Dusun Brajan, Bantulan, Miren, Kemasan. Jenon, dan Karanganom. 


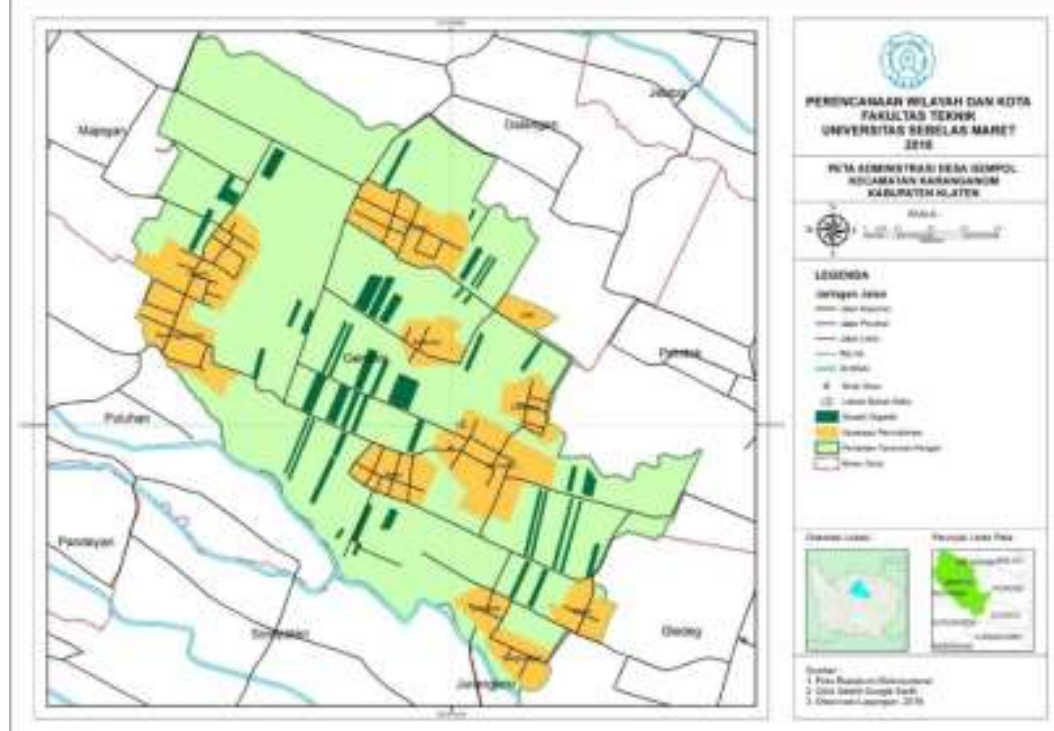

Gambar 3. Kawasan Penelitian Desa Gempol

4.2 Karakteristik Spasial Pola Hulu Hilir Pertanian Padi Organik

\subsubsection{Bahan Baku}

\section{A. Asal Bahan Baku}

Mayoritas petani mendapatkan bahan baku dari dalam Desa Gempol. Hal ini sesuai dengan SOP pertanian padi organik. Selain itu menurut (Weber, 1909) lokasi bahan baku yang dekat dan mudah dijangkau adalah lokasi yang optimal. Lokasi pengadaan bahan baku $80 \%$ dapat dijangkau dengan kendaraan roda empat sedangkan sisanya menggunakan kendaraan roda dua. Kemudahan jangkauan lokasi bahan baku menurut Isard dalam (Adisasmita, 2008) juga harus dipertimbangkan, karena semakin mudah dijangkau maka untuk mendapatkan bahan baku tidak memerlukan effort yang lebih besar.

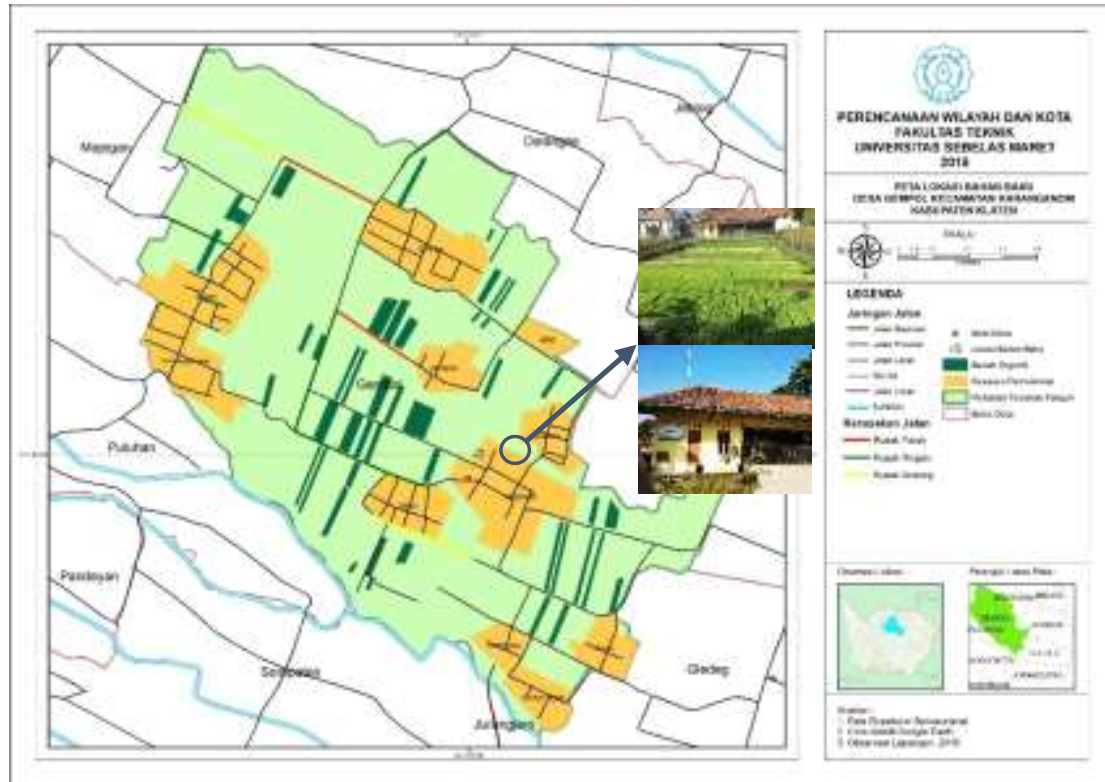

Gambar 4. Peta Lokasi Bahan Baku Desa Gempol 


\section{B. Prasarana Jalan Lokasi Bahan Baku}

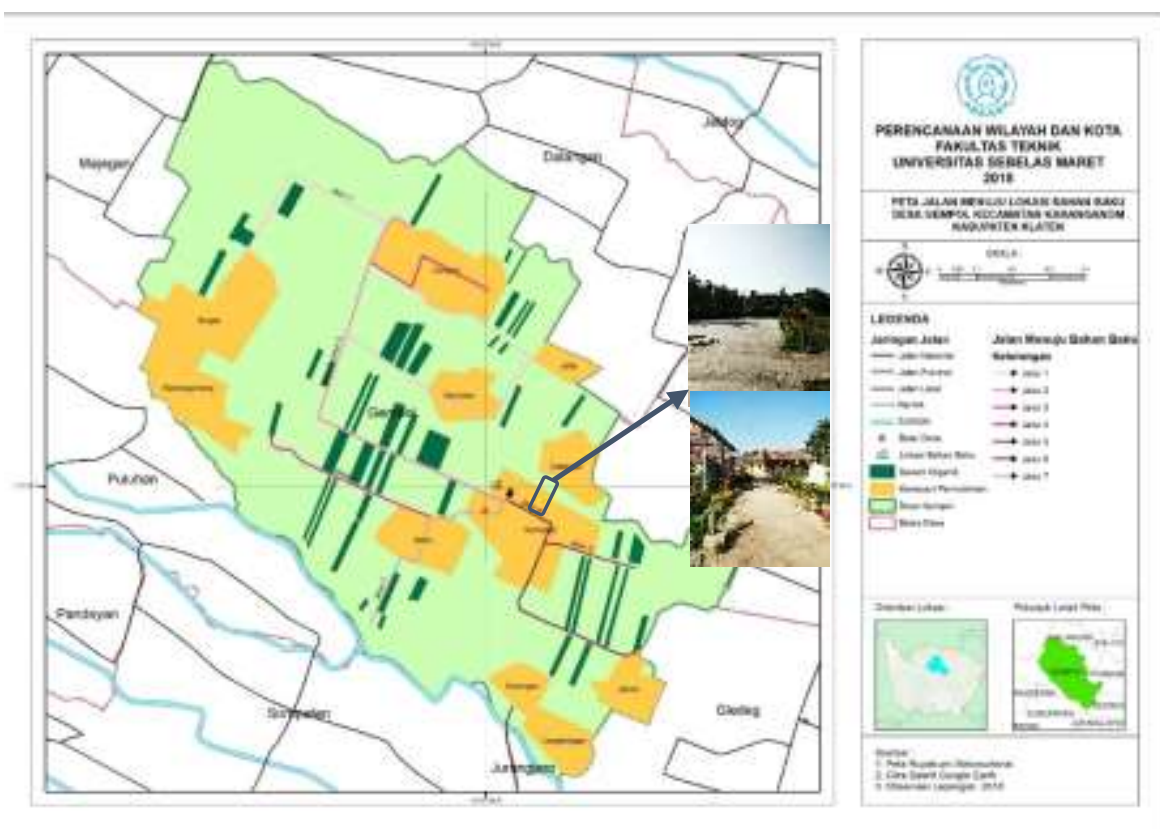

Gambar 5. Peta Prasarana Jalan Lokasi Pengadaan Bahan Baku

Lebar jalan di lokasi bahan baku adalah $4 \mathrm{~m}-5 \mathrm{~m}$ dengan kondisi baik dan sudah mengalami perkerasan. 90\% kondisi jalan dalam keadaan baik, hal ini sesuai dengan data yang diperoleh. Sesuai dengan teori yang diungkapkan oleh Von Thunen dalam (Yunus, 2006) serta Isard dalam (Adisasmita, 2008) maka jaringan jalan memiliki peran penting dalam proses perolehan bahan baku hingga proses pemasaran. Semakin baik tingkat aksesibilitas maka akan semakin tinggi keuntungan yang didapatkan.

\section{Cara Menghimpun Bahan Baku}

Terdapat dua cara menghimpun bahan baku yaitu petani mengambil melalui pengepul dan petani menerima langsung dari produsen atau pengelola. $86 \%$ petani menerima bahan baku melalui perantara karang taruna dan wanita tani, sedangkan sisanya mengambil langsung ke lokasi penjualan. Sesuai dengan yang dikemukakan oleh (Ahrayi, 2003) bahwa bahan baku dapat diperoleh melalui perantara ataupun diperoleh secara langsung. 
4.2.2 Budidaya

\section{A. Lokasi Budidaya}

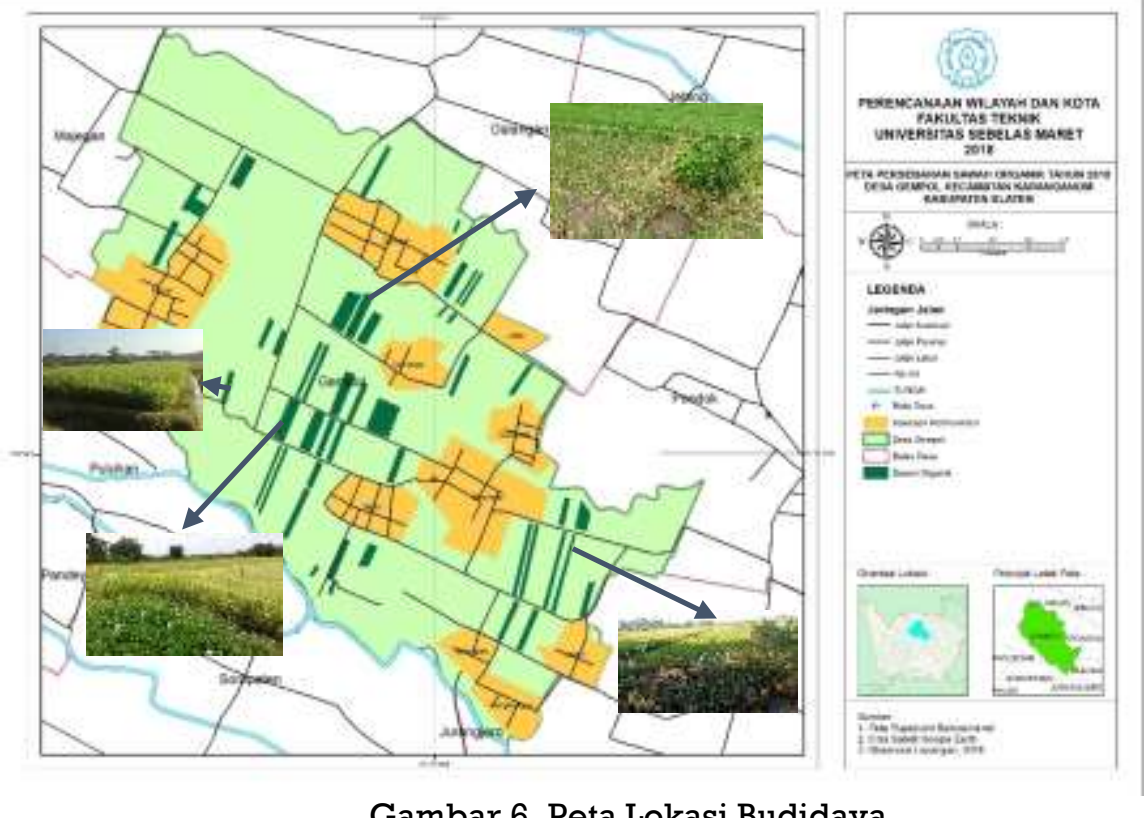

Gambar 6. Peta Lokasi Budidaya

Lokasi budidaya padi organik tersebar di beberapa dusun di Desa Gempol, antara lain Dusun Brajan, Bantulan, Miren, Kemasan. Jenon, dan Karanganom. Jalan menuju lokasi budidaya dapat dijangkau dengan menggunakan kendaraan roda empat, kendaraan roda dua, maupun berjalan kaki. Tetapi jumlah responden tertinggi menyatakan bahwa kendaraan roda empat. Kemudahan akses menurut Alferd Weber dalam (Adisasmita, 2008) merupakan salah satu faktor penting dalam penentuan lokasi yang optimum.

\section{B. Jarak Lokasi Budidaya menuju Lokasi Bahan Baku}

Berdasarkan data tersebut dapat diketahui bahwa seluruh petani menyatakan jarak optimal adalah kurang dari $9 \mathrm{~km}$. Sesuai dengan teori Hoover dalam (Adisasmita, 2008) bahwa lokasi budidaya yang optimum akan mendekati bahan baku. Jarak ini akan menghemat biaya serta waktu tempuh pada saat mengambil bahan.

\section{Prasana Jalan Lokasi Budidaya}

$43 \%$ petani menyatakan kondisi jalan dalam keadaan baik dan sudah perkerasan apsal. Terdapat $37 \%$ petani yang menyatakan lokasi budidaya berada pada jalan lingkungan dengan perkerasan aspal dan lebar jalan antara 2 - 3meter. Sedangkan $20 \%$ petani yang menyatakan bahwa kondisi jalan di lokasi budidaya dalam keadaan bukan aspal serta lebar jalan $<1$ meter. Aksesibilitas merupakan salah satu komponen yang dapat menentukan lokasi yang optimum. Sesuai pendapat Von Thunen dalam (Yunus, 2006), Weber dan Isard dalam (Adisasmita, 2008). 

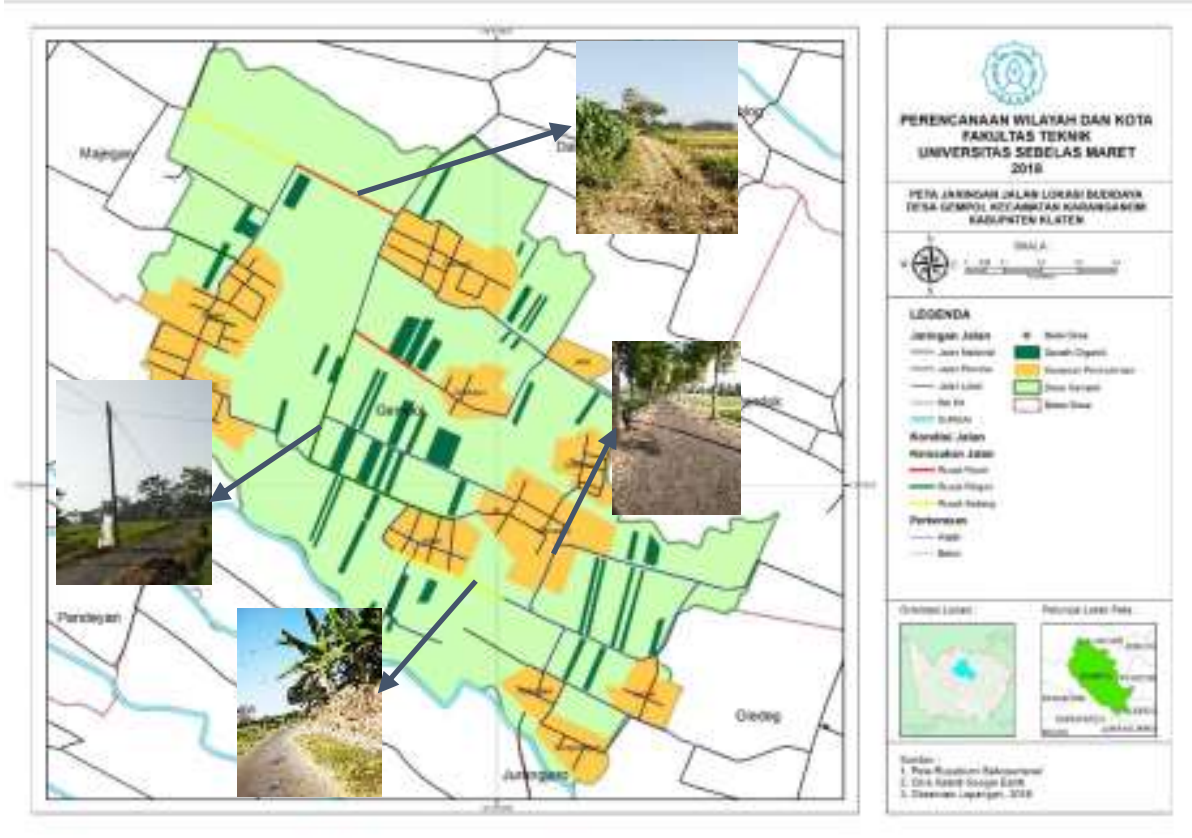

Gambar 7. Peta Prasarana Jalan Lokasi Budidaya

\subsubsection{Pasar}

\section{A. Lokasi Pasar}

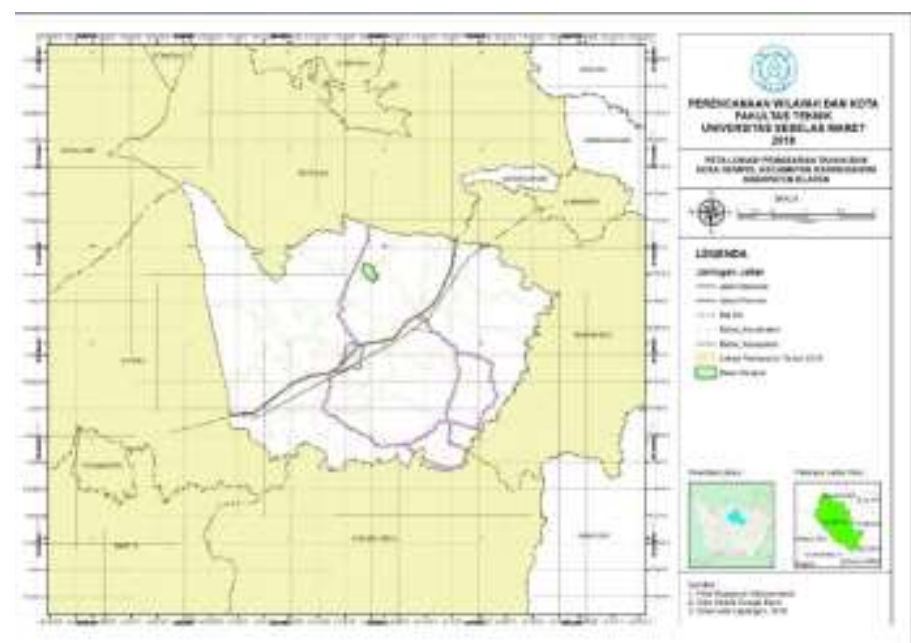

Gambar 8. Peta Lokasi Pasar Padi Organik

88\% petani menyatakan lokasi pasar mayoritas terdapat di luar Kabupaten Klaten, 6\% petani menyatakan bahwa lokasi pasar di luar Kecamatan Karanganom, dan sisanya menyatakan lokasi pasar di dalam Kecamatan Karanganom, Klaten. Menurut August Losch dalam (Syafrizal, 2008) semakin luas jangkauan pasar maka keuntungan yang diperoleh akan semakin besar. Karena wilayah pemasaran semakin banyak dan luas. 
Martha Dwi Nugrahaeni, dkk, Pengaruh Karakter...

\section{B. Jarak Lokasi Pasar Menuju Lokasi Budidaya}

Rata-rata jarak lokasi pasar dengan lokasi budidaya adalah $60 \mathrm{~km}$, maka $88 \%$ petani menyatakan bahwa jarak lebih dari $9 \mathrm{~km}$ sedangkan, 6\% petani menyatakan jaraknya antara 4.6 sampai dengan $9 \mathrm{~km}$, dan sisanya menyatakan jarak $0-4.5 \mathrm{~km}$. Menurut August Losch dalam Budiharsono, 2001 semakin luas jangkauan pasar maka akan semakin baik, tetapi semakin jauh jarak pasar maka biaya transportasi akan semakin meningkat.

\section{Moda Transportasi Menuju Lokasi Pasar}

47 petani atau $92.15 \%$ petani menyatakan bahwa moda transportasi yang digunakan untuk mengangkut hasil produksi adalah kendaraan roda empat, dan sisanya $7.85 \%$ menggunakan kendaraan roda dua. Menurut Teori Hoover dalam (Adisasmita, 2008) produk akhir yang diangkut dengan jenis sarana angkutan dapat dikaitkan dengan besarnya biaya yang dikeluarkan. Sarana angkutan dapat berupa truck, kapal laut, ataupun pesawat terbang.

\subsection{Karakter Spasial Pola Hulu Hilir Pertanian Padi Organik}

Lokasi bahan baku berada di Dusun Kemasan, kemudian terjadi pola distribusi melalui anggota Karang Taruna dan Wanita Tani ke lokasi budidaya. Sedangkan untuk jejaring pendistribusian lokasi bahan baku ini mengikuti pola jalan yang ada, sesuai dengan teori yang dikemukakan oleh Babcock, dalam (Yunus, 2006). Perkembangan keruangan dipengaruhi oleh jaringan transportasi yang ada
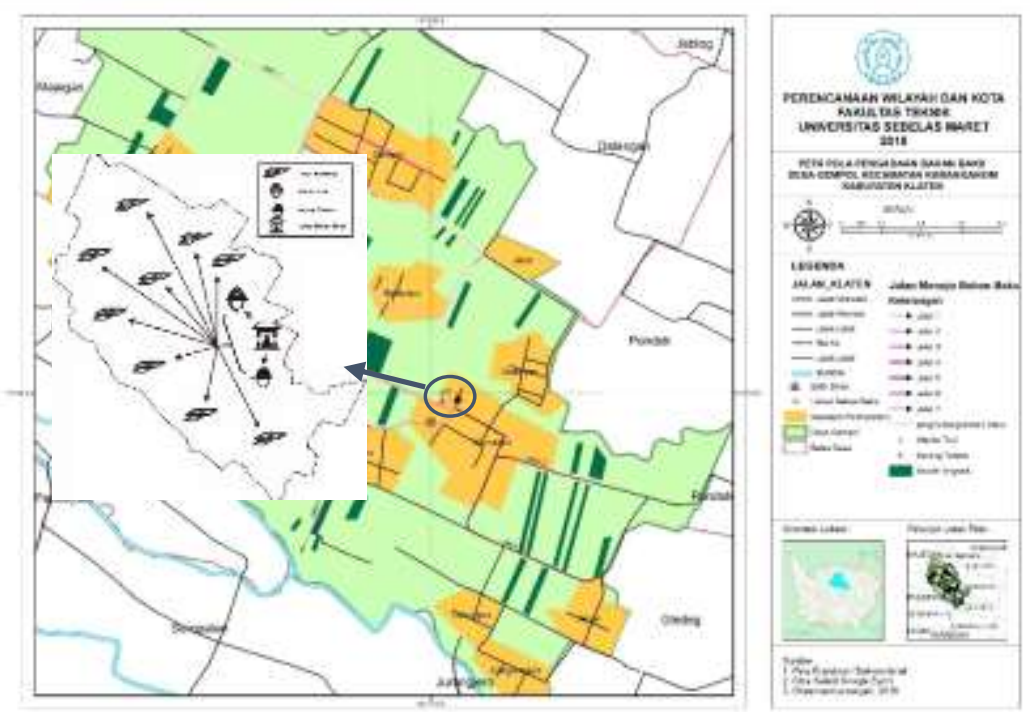

Sesuai dengan peta disamping, pola pengadaan bahan baku adalah pola memusat. Hal ini sesuai adopsi teori perkembangan kota yang disampaikan oleh Burgess, dalam (Yunus, 2006) bahwa terdapat satu inti yang dijadikan sebagai poros atau pusat. Kemudian pusat tersebut memberikan dampak perkembangan kepada daerah yang ada di sekitarnya.

Gambar 9. Peta Pola Pengadaan Bahan Baku 


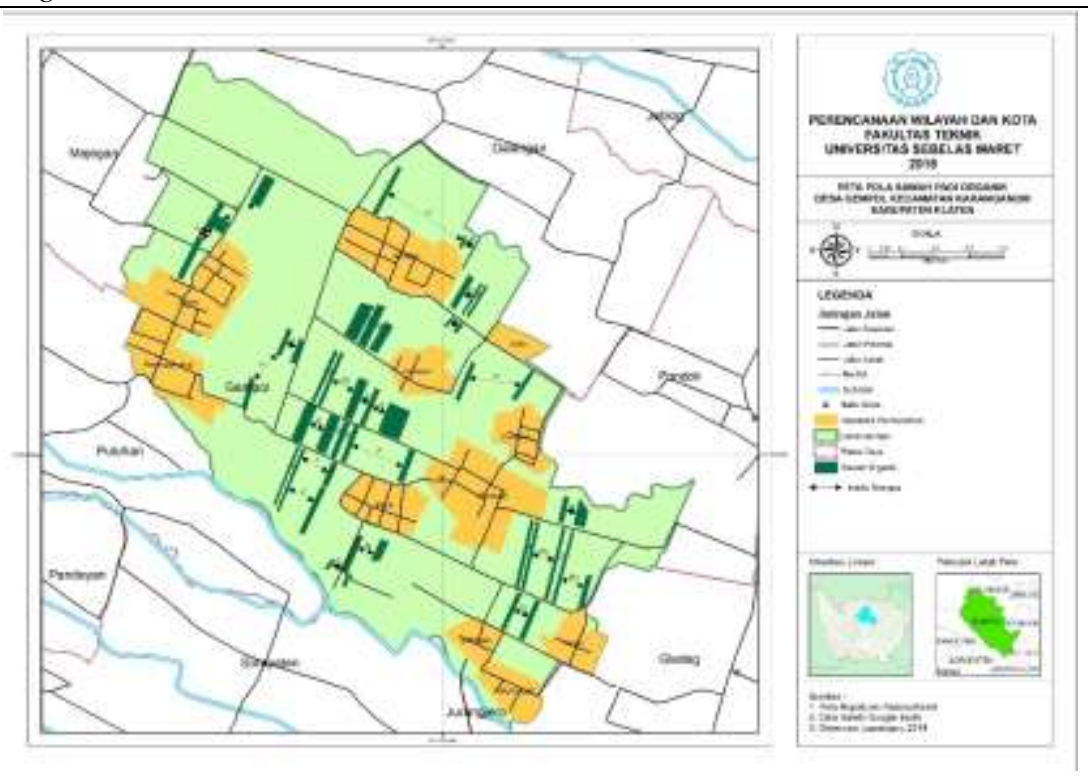
Pola budidaya padi organik ditentukan menggunakan teori indeks tetangga terdekat.

Hasil perhitungan indeks tetangga terdekat adalah 0,29. Hal ini menunjukkan bahwa sawah organik di Desa Gempol termasuk ke dalam klasifikasi menggerombol atau cluster pattern.

Gambar 10. Pola Lokasi Budidaya

Langkah 1: Menghitung jarak rata-rata terdekat antar industri $\mathrm{Ju}=\frac{\text { total jarak tetangga terdekat }}{\text { banyak titik tetangga terdekat }}=\frac{1.74 \mathrm{~km}}{33}=0,053 \mathrm{~km}$

Langkah 2 : Menghitung kepadatan industri tiap $1 \mathrm{~km}$ $\mathrm{P}=\frac{\text { jumlah titil sawah }}{\text { total luas hawasan penelitian }}=\frac{51}{1,54 \mathrm{~km}^{2}}=33.12^{2}$

Langkah 3 : Menghitung jarak rata-rata andaikan semua titik random Th $=\frac{1}{\sqrt[2]{P}}=\frac{1}{\sqrt[3]{16.9}}=0.17$

Langkah 4 : Menghitung indeks tetangga terdekat $\mathrm{T}=\frac{J u}{J h}=\frac{0,05}{0.17}=0,29$

Sedangkan pola pemasaran yang terbentuk sesuai dengan teori August Losch dalam (Budiharsono, 2001) tentang teori market area. Apabila luas pasar yang dikuasai semakin besar maka keuntungan yang didapatkan akan semakin besar. August Losch mengemukakan bahwa lokasi pasar sangat berpengaruh terhadap jumlah konsumen yang dapat digarapnya. Menurut (Bertrand, 1978) membentuk sebuah pola yang tersebar yang dimungkinkan karena perbedaan produksi dan permintaan sehingga dapat disebut juga trade center community.

Berdasarkan hasil skoring yang telah dilakukan maka dapat dirangkum menjadi:

Tabel 4. Rangkuman Hasil Skoring Variabel Karakter Spasial

\begin{tabular}{|c|c|c|c|}
\hline Variabel & Sub Variabel & Kondisi & Skor \\
\hline \multirow{4}{*}{$\begin{array}{l}\text { Bahan } \\
\text { baku }\end{array}$} & \multirow[t]{2}{*}{ Asal Bahan baku } & Berasal dari dalam Desa Gempol & \multirow[t]{2}{*}{2.9} \\
\hline & & $\begin{array}{l}\text { Lokasi bahan baku dapat dijangkau dengan kendaran } \\
\text { roda dua dan empat }\end{array}$ & \\
\hline & $\begin{array}{l}\text { Prasarana jalan lokasi } \\
\text { bahan baku }\end{array}$ & Jalan dengan perkerasan dan lebar 3,5 - $6 \mathrm{~m}$ & 2.9 \\
\hline & $\begin{array}{l}\text { Cara menghimpun bahan } \\
\text { baku }\end{array}$ & $\begin{array}{l}\text { Bahan baku diterima dari pengepul maupun dari } \\
\text { Karang Taruna dan Wanita Tani }\end{array}$ & 2.86 \\
\hline Budidaya & Lokasi Budidaya & $\begin{array}{l}\text { Lokasi bahan baku dapat dijangkau dengan kendaraan } \\
\text { roda dua dan empat }\end{array}$ & 2.33 \\
\hline
\end{tabular}


Martha Dwi Nugrahaeni, dkk, Pengaruh Karakter...

\begin{tabular}{|l|l|l|c|}
\hline Variabel & \multicolumn{1}{|c|}{ Sub Variabel } & \multicolumn{1}{|c|}{ Kondisi } & \multicolumn{1}{|c|}{ Skor } \\
\hline & $\begin{array}{l}\text { Jarak lokasi bahan baku } \\
\text { ke lokasi budidaya }\end{array}$ & $\begin{array}{l}\text { Jarak lokasi budidaya dengan lokasi bahan baku } \\
\text { adalah <9 km }\end{array}$ & 3 \\
\cline { 2 - 5 } & $\begin{array}{l}\text { Prasarana jalan lokasi } \\
\text { budidaya }\end{array}$ & $\begin{array}{l}\text { Lebar jalan mulai kurang dari l meter sampai dengan 4 } \\
\text { meter, kondisi berlubang hingga tidak berlupang, } \\
\text { dengan atau tanpa perkerasan }\end{array}$ & 2.23 \\
\hline Pasar & Lokasi Pasar & $\begin{array}{l}\text { Lokasi pasar di luar Desa Gempol sampai dengan di } \\
\text { luar Kabupaten Klaten }\end{array}$ & 2.82 \\
\cline { 2 - 5 } & $\begin{array}{l}\text { Jarak lokasi pasar dengan } \\
\text { lokasi budidaya }\end{array}$ & $\begin{array}{l}\text { Rata-rata jarak lokasi pasar dengan lokasi budidaya } \\
\text { adalah 60 km }\end{array}$ & 1.18 \\
\cline { 2 - 5 } & Moda transportasi & Kendaraan roda dua dan empat & 2.92 \\
\hline Jumlah
\end{tabular}

Sumber: Nugrahaeni, 2018

$$
\begin{gathered}
\text { Rata-rata (mean) tiap variabel }=\frac{\sum \text { (Skor Sub variabel) }}{\text { Jumlah sub variabel }} \\
\text { Rata - rata (mean) tiap variabel }=\frac{28.18}{9}=2.57
\end{gathered}
$$

Tabel 5. Ketentuan Skor Komponen Karakter Spasial

\begin{tabular}{|c|c|}
\hline Skor & Keterangan \\
\hline $3,00-2,33$ & Pengaruh kuat \\
\hline $2,32-1,66$ & Pengaruh sedang \\
\hline $1,65-1,00$ & Pengaruh lemah \\
\hline
\end{tabular}

Berdasarkan hasil perhitungan skor tersebut, skor yang didapatkan adalah 2.57. Sehingga dapat diketahui bahwa karakter spasial pola hulu hilir pertanian padi organik memiliki pengaruh kuat terhadap variabel terikat yaitu peningkatan ekonomi pedesaan.

\subsection{Peningkatan Ekonomi Pedesaan}

\subsubsection{Jejaring Ekonomi Pertanian}

Berdasarkan data diatas maka dapat diketahui bahwa 90.2\% jaringan pendistribusian produk padi organik dilakukan melalui kelompok tani dengan memperhitungkan kebutuhan pribadi. Sedangkan sisanya 9.8\% petani melalui persetujuan kelompok tani tanpa memperhitungkan kebutuhan pribadi.

\subsubsection{Tenaga Kerja}

\section{A. Jumlah Tenaga Kerja}

Menurut (Lobley, et al., 2009) peningkatan ekonomi pedesaan ditunjang dengan salah satu faktor yaitu peningkatan jumlah tenaga kerja. Adapun di Desa Gempol tenaga kerja padi organik tidak mengalami peningkatan. Jumlah tenaga kerja masih tetap konstan dari tahun 2016 ke tahun 2018. Menurut (Hermanto, 1989) faktor produksi merupakan salah satu bagian dari ekonomi pertanian. Ekonomi pertanian akan mengalami peningkatan apabila ditunjang dengan penambahan jumlah tenaga kerja. 


\section{B. Upah Tenaga Kerja}

Lain halnya dengan jumlah tenaga kerja yang tidak mengalami peningkatan, upah tenaga kerja padi organik di Desa Gempol mengalami peningkatan. Mayoritas petani atau $88.24 \%$ petani menyatakan bahwa upah tenaga kerja mengalami peningkatan diatas $40 \%$, sedangkan sisanya mengalami peningkatan $20 \%-40 \%$.

\subsubsection{Biaya}

Biaya produksi mengalami penurunan dari tahun 2016 ke tahun 2018. Tahun 2016 total produksi mencapai Rp 2.177.632,00 sedangkan tahun 2018 adalah Rp 1.140.000,00. Rata-rata penurunan yang terjadi adalah 48\%. Hal ini dikarenakan terjadi penghematan pada biaya bahan baku serta biaya operasional lainnya, seperti biaya persiapan lahan, biaya matun, biaya semprot, dan biaya jemur. Sedangkan ada 6 petani yang menyatakan bahwa penurunan yang terjadi adalah $20 \%$ hingga $40 \%$.

\subsubsection{Pendapatan}

Rata-rata peningkatan pendapatan dari tahun 2016 ke tahuh 2018 adalah 55\% dan semua petani mengalami peningkatan pendapatan lebih dari 40\%. Menurut (Lobley, et al., 2009) pertanian organik memberikan manfaat untuk peningkatan pendapatan. (Saptana, et al., 2006) menambahkan, jaminan harga dan pemasaran padi organik dapat dilakukan melalui kemitraan. Padi organik memiliki harga jual yang lebih tinggi dibandingkan dengan padi non organik. Kesejahteraan masyarakat di desa juga akan tercipta, sebab masyarakat desa merasakan keuntungan yang lebih dari pertanian organik (Sriyanto, 2010).

Tabel 6. Rangkuman Hasil Skoring Peningkatan Ekonomi Pedesaan

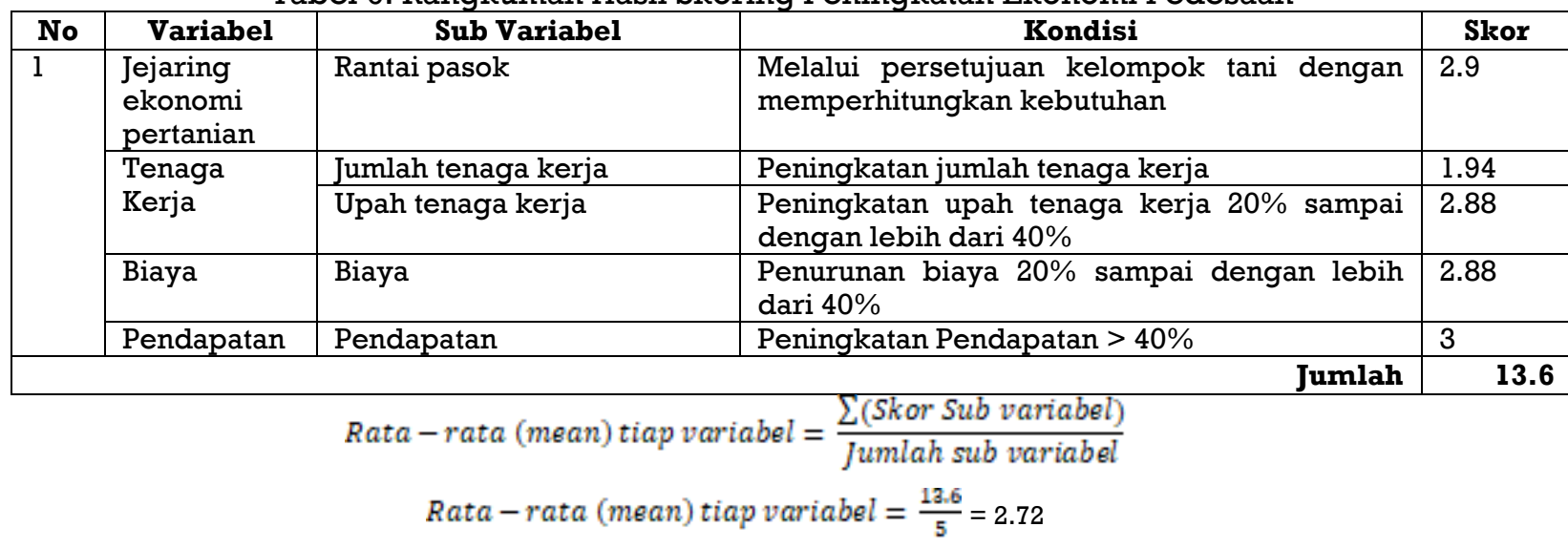

Tabel 7. Ketentuan Skor Komponen Peningkatan Ekonomi Pedesaan

\begin{tabular}{|c|c|}
\hline Skor & Keterangan \\
\hline $3,00-2,33$ & Peningkatan tinggi \\
\hline $2,32-1,66$ & Peningkatan sedang \\
\hline $1,65-1,00$ & Peningkatan rendah \\
\hline
\end{tabular}


Martha Dwi Nugrahaeni, dkk, Pengaruh Karakter...

Peningkatan ekonomi yang ada di Desa Gempol tergolong tinggi. Kategori ini diperoleh dari menghitung rata-rata skor tiap indikator, rata-rata skor tiap sub variabel, dan rata-rata skor tiap variabel. Skor yang diperoleh adalah 2.7 sehingga skor tersebut merupakan peningkatan ekonomi pedesaan yang tinggi.

\subsection{Pengaruh Karakter Spasial Pola Hulu Hilir Pertanian Padi Organik Terhadap Peningkatan Ekonomi Pedesaan}

Tabel 8. Rangkuman Besaran Pengaruh Karakter Spasial Pola Hulu Hilir Pertanian Padi Organik Terhadap Peningkatan Ekonomi Pedesaan

\begin{tabular}{|c|c|c|c|c|c|}
\hline No & $\begin{array}{l}\text { Variabel X } \\
\text { (Variabel Karakter } \\
\text { Spasial Hulu Hilir } \\
\text { Pertanian Padi }\end{array}$ & $\begin{array}{l}\text { Variabel Y } \\
\text { (Variabel } \\
\text { Peningkatan } \\
\text { Ekonomi }\end{array}$ & $\begin{array}{c}\text { Nilai } \\
\mathbf{R}^{2}\end{array}$ & \multicolumn{2}{|c|}{$\begin{array}{c}\text { Keterangan } \\
\text { Berdasarkan Klasifikasi Nilai } \mathbf{R}^{2} \text { dalam } \\
\text { Ghozali (2012) }\end{array}$} \\
\hline 1 & $\begin{array}{ll}\text { - } & \text { Asal Bahan Baku } \\
\text { - } & \text { Prasarana Jalan } \\
\text { Lokasi Bahan } \\
\text { Baku } \\
\text { - Cara } \\
\text { Menghimpun } \\
\text { Bahan Baku }\end{array}$ & $\begin{array}{l}\text { Jejaring } \\
\text { Ekonomi } \\
\text { Pertanian }\end{array}$ & 0.936 & $\begin{array}{l}\text { Karakter spasial } \\
\text { hulu hilir pertanian } \\
\text { padi organik } \\
\text { berpengaruh kuat } \\
\text { terhadap } \\
\text { peningkatan } \\
\text { ekonomi pedesaan }\end{array}$ & \multirow{5}{*}{ 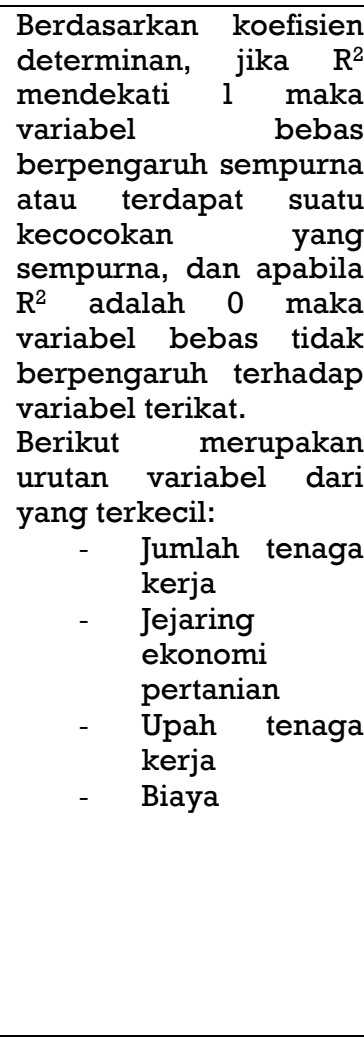 } \\
\hline 2 & $\begin{array}{ll}\text { - } & \text { Lokasi Budidaya } \\
\text { - Jarak Lokasi } \\
\text { Budidaya } \\
\text { dengan Lokasi } \\
\text { Bahan Baku } \\
\text { - Prasarana Jalan }\end{array}$ & $\begin{array}{l}\text { Jumlah Tenaga } \\
\text { Kerja }\end{array}$ & 0.930 & $\begin{array}{l}\text { Karakter spasial } \\
\text { hulu hilir pertanian } \\
\text { padi organik } \\
\text { berpengaruh kuat } \\
\text { terhadap } \\
\text { peningkatan } \\
\text { ekonomi pedesaan }\end{array}$ & \\
\hline 3 & $\begin{array}{l}\text { Lokasi Pasar } \\
\text { - Jarak Lokasi } \\
\text { Pasar dengan } \\
\text { Lokasi Budidaya, } \\
\text { - Moda } \\
\text { Transportasi }\end{array}$ & $\begin{array}{ll}\text { Upah } & \text { Tenaga } \\
\text { Kerja } & \end{array}$ & 0.936 & $\begin{array}{l}\text { Karakter spasial } \\
\text { hulu hilir pertanian } \\
\text { padi organik } \\
\text { berpengaruh kuat } \\
\text { terhadap } \\
\text { peningkatan } \\
\text { ekonomi pedesaan }\end{array}$ & \\
\hline 4 & $\begin{array}{l}\text { Nuenuju Lok } \\
\text { Pasar. }\end{array}$ & Biaya & 0.936 & $\begin{array}{l}\text { Karakter spasial } \\
\text { hulu hilir pertanian } \\
\text { padi organik } \\
\text { berpengaruh kuat } \\
\text { terhadap } \\
\text { peningkatan } \\
\text { ekonomi pedesaan }\end{array}$ & \\
\hline 5 & & Pendapatan & & & \\
\hline
\end{tabular}


Region, Vol. 14, No.2, Januari 2019: 244-266

4.4.1 Pengaruh Karakter Spasial Pola Hulu Hilir Pertanian Padi Organik Terhadap Jejaring Ekonomi Pertanian

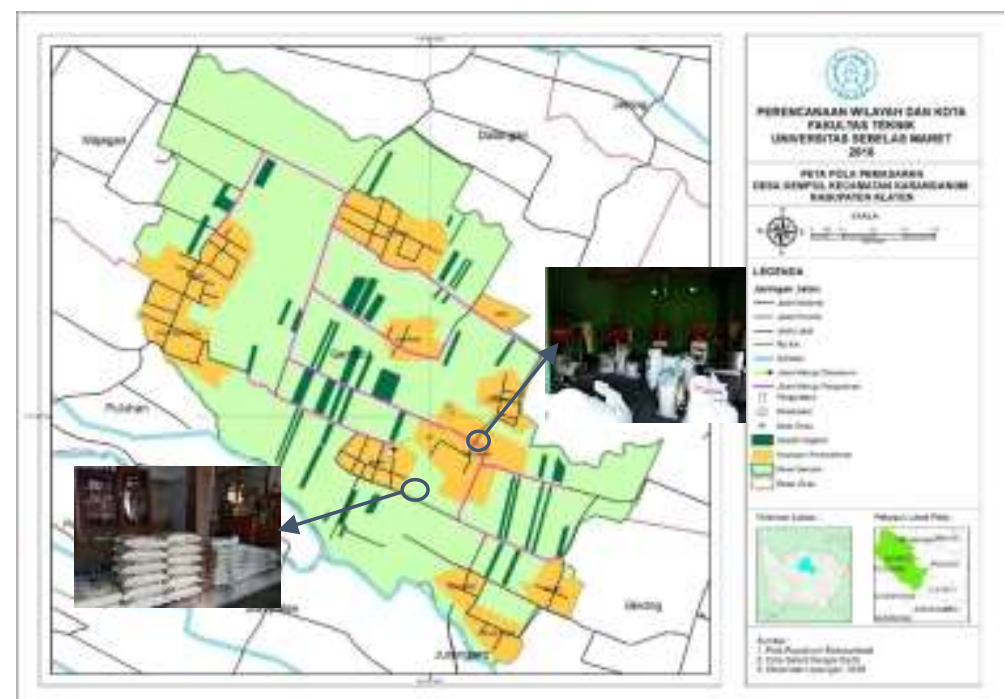

Gambar 11. Peta Jejaring Ekonomi Pertanian

Jejaring ekonomi pertanian merupakan komponen peningkatan ekonomi pedesaan dengan kemampuan menjelaskan 91.5\%. Hal tersebut sesuai dengan teori (August Losch, 1954; Hazell dan Haggblade, 1993; Puglise, 2001; Adisasmita, 2010) yang menyatakan bahwa sebuah karakter spasial yang terbentuk akan membentuk sebuah pola distribusi kegiatan ekonomi yang kompleks. Pola tersebut kemudian membentuk sebuah dimensi dimana di dalamnya terdapat kegiatan ekonomi. Karakter spasial pola hulu hilir memberikan pengaruh terhadap jejaring ekonomi pertanian yang ada karena antara pola dan arus produksi membentuk keseimbangan atau pemusatan sehingga terbentuk sebuah struktur kegiatan berupa jejaring ekonomi pertanian.

4.4.2 Pengaruh Karakter Spasial Pola Hulu Hilir Pertanian Padi Organik Terhadap Jumlah Tenaga Kerja

Jumlah tenaga kerja merupakan komponen dari peningkatan ekonomi pedesaan dengan kemampuan menjelaskan 84\%. Sesuai dengan teori (Hazell dan Haggblade, 1993; Puglise, 2001; Chimura dan Orozobekov, 2009; Adisasmita, 2010) yang menyatakan bahwa konsep tata ruang ekonomi yang dikaitkan dengan modal (tenaga kerja), jaringan transportasi, industri, teknologi pertanian, akan menciptakan perkembangan baru. Pengembangan ekonomi pedesaan terjadi peningkatan kesempatan kerja dan pendapatan rumah tangga serta pengurangan kemiskinan dan pengangguran. 

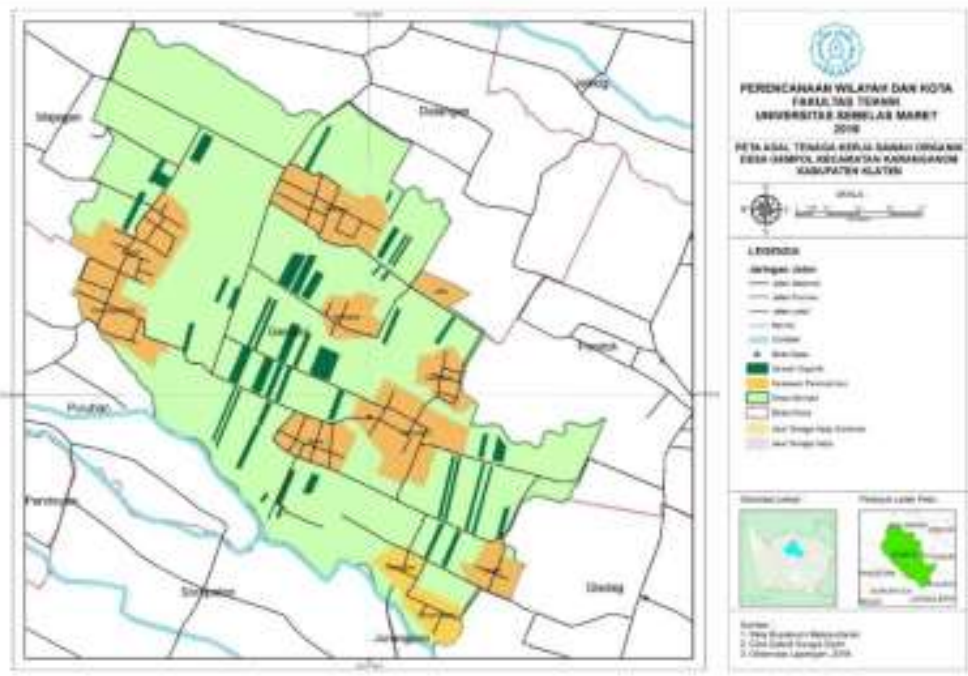

Gambar 12. Peta Asal Tenaga Kerja

4.4.3 Pengaruh Karakter Spasial Pola Hulu Hilir Pertanian Padi Organik Terhadap Upah Tenaga Kerja

Peningkatan upah tenaga kerja merupakan komponen dari peningkatan ekonomi pedesaan dengan kemampuan menjelaskan 91.5\%. Sesuai dengan teori (Von Thunen, 1926; August Losch, 1954; Hazell dan Haggblade, 1993; Puglise, 2001; Adisasmita, 2010) yang menyatakan bahwa konsep tata ruang ekonomi yang dikaitkan dengan modal (tenaga kerja), jaringan transportasi, industri, teknologi pertanian, akan menciptakan perkembangan baru. Peningkatan ekonomi pedesaan dapat terwujud salah satunya dengan komponenen peningkatan jumlah dan upah tenaga kerja. Semakin efektif karakter spasial dan pola yang terbentuk maka keuntungan yang didapatkan akan semakin meningkat, hal ini berarti karakter spasial pola hulu hilir pertanian padi organik dapat memberikan pengaruh terhadap peningkatan ekonomi pedesaan komponen peningkatan upah tenaga kerja.

4.4.4 Pengaruh Karakter Spasial Pola Hulu Hilir Pertanian Padi Organik Terhadap Biaya

Penurunan biaya merupakan komponen dari peningkatan ekonomi pedesaan dengan kemampuan menjelaskan 91.5\%. Hal tersebut sesuai dengan teori (Von Thunen, 1926; August Losch, 1954; Hazell dan Haggblade, 1993; Puglise, 2001; Adisasmita, 2010) yang menyatakan bahwa konsep tata ruang ekonomi yang dikaitkan dengan modal (tenaga kerja), jaringan transportasi, industri, teknologi pertanian, akan menciptakan perkembangan baru. Pola spasial yang terbentuk dari jaringan transportasi dan teori lokasi yang ada akan memberikan efek positif terhadap peningkatan ekonomi pedesaan. Model spasial dari sistem produksi dapat 
Region, Vol. 14, No.2, Januari 2019: 244-266

mempengaruhi besar kecilnya biaya yang dikeluarkan dalam proses produksi. Kesejahteraan masyarakat di desa juga akan tercipta, sebab masyarakat desa merasakan keuntungan yang lebih dari pertanian organik.

Semakin mudah jangkauan bahan baku, lokasi produksi dan lokasi pasar akan menghemat pengeluaran biaya operasional. Karakter spasial yang terbentuk berpengaruh terhadap purunan biaya produksi.

4.4.5 Pengaruh Karakter Spasial Pola Hulu Hilir Pertanian Padi Organik Terhadap Pendapatan

Pendapatan petani organik tergantung pada produktivitas padi yang dihasilkan. Semakin tinggi produktivitas, maka keuntungan petani organik akan semakin besar. Menurut (Lobley, et al., 2009) pertanian organik memberikan manfaat untuk peningkatan pendapatan. (Saptana, et al., 2006) menambahkan, jaminan harga dan pemasaran padi organik dapat dilakukan melalui kemitraan. Padi organik memiliki harga jual yang lebih tinggi dibandingkan dengan padi non organik. Kesejahteraan masyarakat di desa juga akan tercipta, sebab masyarakat desa merasakan keuntungan yang lebih dari pertanian organik (Sriyanto, 2010).

Peningkatan pendapatan yang terjadi selama tahun 2016 ke tahun 2018 adalah lebih dari $40 \%$ sehingga data tersebut tidak dapat diinput untuk tahap analisis menggunakan software SPSS karena data yang sangat homogen.

\section{KESIMPULAN}

Berdasarkan hasil analisis spasial pola pengadaan bahan baku yang terbentuk adalah memusat atau konsentris, sesuai yang dikemukakan oleh Burgess bahwa terdapat satu pusat yang kemudian memberikan pelayanan kepada wilayah di sekiarnya. Selanjutnya pola dari lokasi budidaya yang ada di Desa Gempol adalah pola menggerombol atau cluster pattern berdasarkan perhitungan analisis tetangga terdekat (Bintarto, 1989). Pola pasar berdasarkan teori Losch tentang market area yang terbentuk dari produk padi organik adalah menyebar membentuk sebuah pola yang tersebar yang dimungkinkan karena perbedaan produksi dan permintaan sehingga dapat disebut juga trade center community. Berdasarkan analisis skoring pada variabel karakter spasial didapatkan hasil 2.57 yang berarti variabel tersebut memberikan pengaruh kuat terhadap variabel bebas. 
Martha Dwi Nugrahaeni, dkk, Pengaruh Karakter...

Sedangkan analisis skoring pada variabel peningkatan ekonomi pedesaan didapatkan hasil 2.72 yang berarti peningkatan ekonomi di Desa Gempol tergolong tinggi. Selanjutnya berdasarkan hasil analisis regresi linear berganda dengan software SPP maka seluruh variabel karakter spasial pola hulu hilir pertanian padi organik berpengaruh kuat terhadap seluruh komponen peningkatan ekonomi pedesaan yang meliputi jejaring ekonomi pertanian, jumlah tenaga kerja, upah tenaga kerja, dan biaya. Komponenn pendapatan tidak dapat dihitung menggunakan software SPSS dikarenakan data yang dihasilkan sangat homogen. Nilai yang $R^{2}$ adalah $0.90-0.936$ yang mengindikasikan pengaruh antar variabel adalah kuat.

\section{REFERENSI}

Adisasmita, R., 2008. Pengembangan Wilayah : Konsep dan Teori. I ed. Yogyakarta: Graha Ilmu.

Adisasmita, R., 2010. Pembangunan Kawasan dan Tata Ruang. I ed. Yogyakarta: Graha Ilmu.

Ahrayi, A., 2003. Manajemen Produksi Perencanaan SIstem Produksi. Yogyakarta: BPFE UGM.

Andoko, A., 2004. Budidaya Padi Secara Organik. Jakarta: Penebar Swadaya.

Baroto, T., 2002. Perencanaan dan Pengendalian Produksi. Jakarta: Ghalia Indonesia.

Bengtsson, J., Ahnstrom, J. \& Weibull, A.-C., April 2015. The Effects of Organic Agricuture on Biodiversity and Abudance : A Meta-Analysis. 42(2), pp. 261269.

Bertrand, A. L., 1978. Rural Sociology. London: Book Company Inc.

Bintarto, 1989. Interaksi Desa Kota dan Permasalahannya. Jakarta: Ghalia Indonesia.

Budiharsono, S., 2001. Teknik Analisis Pembangunan Wilayah Pesisir. Jakarta: Pradnya Paramita.

Hermanto, F., 1989. Ilmu Usahatani. Jakarta: Penebar Swadaya.

Isard, W., 1956. Location and Space Economy. Cambridge: MIT Press.

Lobley, M., Butter, A. \& Reed, M., 2009. The Contribution Of Organic Farming to Rural Development : An Exploration Of The Socio-Economic Linkages Of Organic and Non-organic Farm in England. 26(3), pp. 723-735.

Losch, A., 1940. The Economic of Location. Jerman: Yale University Press.

Mayrowani, H., Desember 2012. Pengembangan Pertanian Organik di Indonesia. 30(2), pp. 91-108.

Mirsa, R., 2012. Elemen Tata Ruang Kota. 1 ed. Yogyakarta: Graha Ilmu.

M. \& Maghfiroh, N., 2010. Aplikasi Teknik Pengambilan Keputusan dalam Manajemen Rantai Pasok. Bogor: IPB Press.

Puglise, P., 2001. Organic Farming and Sustainable Rural Development : A Multifaceted and Promising Convergence. 41(1), pp. 112-130.

Rustiadi, E., Saefulhakim, S. \& Panuju, D. R., 2011. Perencanaan dan Pengembangan Wilayah. 2 ed. Jakarta: Yayasan Pustaka Obor Indonesia.

Said, E. \& AH, I., 2001. Manajemen Agribisnis. Jakarta: Ghalia Indonesia.

Saptana, Mayrowani, H., Agustin, A. \& S., 2006. Analisis Kelembagaan Kemitraan Rantai Pasok Komoditas Holtikultura. In: Bogor: Pusat Penelitian Sosial Ekonomi Pertanian.

Saragih, B., 1999. Pembangunan Agribisnis Sebagai Penggerak Utama Ekonomi Daerah di Indonesia. 
Region, Vol. 14, No.2, Januari 2019: 244-266

Saragih, E. S., 2010. Pertanian Organik. Jakarta: Penebar Swadaya.

Saragih, J. R., 2015. Perencanaan Wilayah dan Pengembangan Ekonomi Lokal Berbasis Pertanian. l ed. Yogyakarta: Pustaka Belajar.

Schutjer, W., 1991. Rural Development and Extension. Jurnal of Extension, Volume 1, p. 29.

Smith, D. M., 1987. Neoclassical Location Theory. London: Mac Millen.

Soehardi, S., 1992. Marketing Praktis. Yogyakarta: BPFE UGM.

Soekartawi, A., Soeharjo, J. L., Dillon, J. \& Brian, H., 1989. Ilmu Usahatani dan Penelitian untuk Pengembangan Petani Kecil. Jakarta: UI Press.

Sriyanto, S., 2010. Panen Duit Bisnis Padi Organik. Jakarta: PT AgroMedia Pustaka.

Sumodiningrat, G., 2000. Pembangunan Ekonomi Melalui Pengembangan Pertanian. Jakarta: PT Bina Rena Pariwisata.

Supartama, M., Antara, M. \& Rauf, R. A., Juni, 2013. Analisis Pendapatan dan Kelayakan Usahatani Padi Sawah di Subak Baturiti Desa Balinggi Kecamatan Balinggi Kabupaten Parigi Moutong. pp. 166-172.

Syahza, A., 2013. Ekonomi Pembangunan. 14(1), pp. 126-139.

Tohir, K., 1983. Seuntai Pengetahuan Tentang Usaha Tani Indonesia. Jakarta: Bina Grafika.

Tuoministo, H., Hodge, I., Riordan, P. \& Macdonald, D., 2012. Does Organic Farming Reduce Environmental Impact? - A Meta-analysis of European Research. Volume 112, pp. 309-320.

U.N, D. H., Soelistijadi, R. \& S., 2005. Pemanfaatan Analisis Spasial Untuk Pengolahan Data Spasial Sistem Informasi Geografi. Jurnal Teknologi Informasi, Volume X, pp. 108-116.

Von Thunen, J. H., 1966. Von Thunen's Isolated State. London: Pergamon Press.

Weber, A., 1909. Theory of The Locational of Industries. Chicago: University of Chicago Press.

Yunus, H. S., 2006. Struktur Tata Ruang Kota. VI ed. Yogyakarta: Pustaka Pelajar. 2007.UU No. 26 Tentang Penataang Ruang .2002.SNI-01-6729-2002 Tentang Pertanian Organik 